\title{
GENOTYPIC RESPONSE OF TWO SOYBEAN VARIETIES WITH REDUCED CONTENT OF KTI TO APPLICATION OF DIFFERENT NITROGEN LEVEL
}

\author{
V. Randjelović ${ }^{1}$, S. Prodanović ${ }^{2}$ Z. Tomić ${ }^{1}$, Z. Bijelić ${ }^{1}$ \\ ${ }^{1}$ Institute for Animal Husbandry, 11080 Belgrade, Republic of Serbia \\ ${ }^{2}$ Faculty of Agriculture, 11080, Belgrade, Republic of Serbia \\ Corresponding author: violetarandjelovic@yahoo.com \\ Original scientific paper
}

Abstract: The aim of this investigation was to estimate the effects of different amounts of nitrogen on the grain yield and nutritive value in two soybean genotypes (Laura and Lana). Studied varieties belong to different maturity groups (Laura is in the group I, while Lana is in the group II) and they both have reduced content of Kunitz trypsin inhibitor (KTI). Four treatments of fertilization were tested: $0 \mathrm{~kg} \mathrm{~N} \mathrm{ha}{ }^{-1}, 30 \mathrm{~kg} \mathrm{~N}^{-1}, 60 \mathrm{~kg} \mathrm{~N} \mathrm{ha}^{-1}$ and $90 \mathrm{~kg} \mathrm{~N}^{-1}$. Field trials were carried out in dry land farming, at location Putinci, during the years 2008 and 2009. In both research years, variety Lana had higher grain yield and oil content then variety Laura. Method of nitrogen fertilization has been proved as an effective tool for increasing of grain yield and protein content in both varieties. The results of the study showed that application of $90 \mathrm{~kg} \mathrm{~N} \mathrm{ha}^{-1}$ increased the grain yield and protein content of soybean more than application of other treatments $\left(0,30\right.$ and $60 \mathrm{~kg} \mathrm{~N} \mathrm{Na}^{-}$ $\left.{ }^{1}\right)$. All nitrogen fertilization levels decreased the oil content.

Key words: genotype, grain yield, nitrogen level, nutritive value, soybean

\section{Introduction}

As the main source of vegetable protein, soybean plays an important role in the world of animal feed and food production. Soybean is an important source of quality, inexpensive protein and oil. Soybean typically contains about $40 \%$ protein and $20 \%$ oil. From the point of view of agricultural production, nitrogen deficiency in the soil results in significant yield losses and yield quality reduction (Marinković et al., 2010). There is speculation that the ability of soybean to fix atmospheric $\mathrm{N}$ is not always adequate for maximum grain yield (Wesley et al., 1998). Research by Starling et al. (2000) of soybean following corn in southern Alabama showed that plant growth and grain yield were higher when fertilizer $\mathrm{N}$ was applied as starter. Further research in Minnesota found that application of $\mathrm{N}$ in-season did not alter 
soybean yields or oil concentration, and the impact on protein was minimal (Schmitt et al., 2001). Živanović et al. (2000) obtained the highest grain yield of soybean at the level of $100 \mathrm{~kg} \mathrm{~N} \mathrm{ha}^{-1}$, as well as with inoculation so without inoculation, and the lowest in variants without fertilization and inoculation. In variants without inoculation, Đukić et al. 2010, obtained the highest grain yield of soybean at the level of $250 \mathrm{~kg} \mathrm{~N} \mathrm{ha}^{-1}$ compared to control, $50 \mathrm{~kg} \mathrm{~N} \mathrm{ha}^{-1}, 100 \mathrm{~kg} \mathrm{~N}$ $\mathrm{ha}^{-1}$ and $150 \mathrm{~kg} \mathrm{~N} \mathrm{ha}^{-1}$. One of the limitations to an increased use of grain legumes as feed is the presence of diverse compounds in their grain, commonly referred to as anti-nutritional factors, that both decrease nutritive value of grain legumes and, if taken in larger amounts, cause health problems that may be fatal for animals (Mikic et al., 2009). Laura and Lana are soybean genotypes with reduced content of KTI (Srebrić et al., 2008). This trait makes them suitable for direct feeding in adult non-ruminant animals without previous thermal processing (Glamočlija, 2004; Ranđelović et al., 2009). Perić et al. (2009) reported that application of $60 \mathrm{~kg} \mathrm{~N}^{-}$ ${ }^{1}$ increased the protein content more than application of treatments 0,30 and $90 \mathrm{~kg}$ $\mathrm{N}$ ha ${ }^{-1}$.

The aim of this investigation was to estimate the effects of different amounts of nitrogen on the grain yield, raw protein and oil grain content in two soybean genotype (Laura and Lana).

\section{Materials and Methods}

Effects of mineral nitrogen nutrition on grain yield and nutritive value of soybean genotypes were analyzed in two-year researches, conducted on the experimental fields in the village of Putinci (region of Srem), during years 2008 and 2009. The tests were carried out on calcareous chernozem soil type. The main characteristics of the soil (depth: 0-50 cm) were: $\mathrm{pH}$ in $\mathrm{KCl}-6.3$ (neutral reaction); $\mathrm{pH} \mathrm{u} \mathrm{H}_{2} \mathrm{O}-7.5$ (weakly alkaline reaction); $\mathrm{CaCO}_{3}-7.6 \%$ (carbonate); humus -2.19 , total $\mathrm{N}-0.10 \%$. The soil contained 15.9 and $23.1 \mathrm{mg} / 100 \mathrm{~g}$ soil phosphorus and potassium, respectively.

Two soybean genotypes (Laura and Lana) were used as material. Soybean genotypes, Laura and Lana, are cultivars with specific properties and have reduced content of KTI. Plots were organized as a randomized block system design in four replications. Four treatments of fertilization were tested: $0 \mathrm{~kg} \mathrm{~N}^{-1}$ (control), 30 $\mathrm{kg} \mathrm{N} \mathrm{ha}{ }^{-1}, 60 \mathrm{~kg} \mathrm{~N} \mathrm{ha}^{-1}$ and $90 \mathrm{~kg} \mathrm{~N} \mathrm{ha}^{-1}$. Mineral nutrition Urea $(46 \% \mathrm{~N})$ was applied at the time of sowing. In both years planting was done in April. Planting was done in the traditional Serbian way, which was plant-to-plant spacing of 3-4 $\mathrm{cm}$ within a row. Plots were four rows wide and $5 \mathrm{~m}$ long with a $0.5 \mathrm{~m}$ row-to-row spacing. Preceding crop was winter wheat. A standard cultivation practice was applied. 
Soybean harvest was performed manually. Grain yield is calculated on a $13 \%$ moisture basis. After harvest, samples were taken for chemical analysis. Protein and oil contents in grain were determined by instrument DICKEY-John, NIR Analyzer (INSTALAB 600 series). Data were processed by ANOVA. Test of difference significance between treatments were estimated by LSD.

\section{Results and Discussion}

Average grain yield, for two years, two cultivars and four nitrogen levels was $4.030 \mathrm{tha}^{-1}$. In 2008, average grain yield was higher $1.815 \mathrm{t} \mathrm{ha}^{-1}(36.76 \%)$ then in 2009 (Table 1).

Table 1. Effect of different nitrogen rates on grain yield $\left(\mathrm{t} \mathrm{ha}^{-1}\right)$ in soybean genotypes with reduced content of KTI

\begin{tabular}{|c|c|c|c|c|c|}
\hline \multirow{2}{*}{ Year } & \multirow{2}{*}{$\begin{array}{l}\text { N levels } \\
\text { (B) }\end{array}$} & \multicolumn{4}{|c|}{ Grain yield } \\
\hline & & Laura & Lana & $\mathrm{M}$ & Index $(\%)$ \\
\hline \multirow{6}{*}{2008} & 0 & 4.572 & 4.736 & 4.654 & 100.00 \\
\hline & 30 & 4.826 & 4.890 & 4.858 & 104.38 \\
\hline & 60 & 4.903 & 5.230 & 5.067 & 108.87 \\
\hline & 90 & 5.026 & 5.310 & 5.168 & 111.04 \\
\hline & $\mathrm{M}$ & 4.832 & 5.042 & 4.937 & - \\
\hline & Index $(\%)$ & 100.00 & 104.35 & 100.00 & - \\
\hline \multirow{6}{*}{2009} & 0 & 2.781 & 2.905 & 2.843 & 100.00 \\
\hline & 30 & 2.946 & 3.132 & 3.039 & 106.89 \\
\hline & 60 & 3.128 & 3.258 & 3.193 & 112.31 \\
\hline & 90 & 3.315 & 3.512 & 3.414 & 120.08 \\
\hline & $M$ & 3.042 & 3.202 & 3.122 & - \\
\hline & Index $(\%)$ & 100.00 & 105.26 & 63.24 & - \\
\hline \multirow{6}{*}{ M } & 0 & 3.677 & 3.820 & 3.749 & 100.00 \\
\hline & 30 & 3.886 & 4.011 & 3.949 & 105.33 \\
\hline & 60 & 4.016 & 4.244 & 4.093 & 109.18 \\
\hline & 90 & 4.170 & 4.411 & 4.291 & 114.46 \\
\hline & $\mathrm{M}$ & 3.937 & 4.122 & 4.030 & - \\
\hline & Index $(\%)$ & 100.00 & 104.70 & - & - \\
\hline
\end{tabular}

\begin{tabular}{|c|c|c|c|c|c|c|}
\hline \multirow{2}{*}{ LSD } & \multicolumn{3}{|c|}{2008} & \multicolumn{3}{c|}{2009} \\
\cline { 2 - 7 } & $\mathrm{A}$ & $\mathrm{B}$ & $\mathrm{A} * \mathrm{~B}$ & $\mathrm{~A}$ & $\mathrm{~B}$ & $\mathrm{~A} * \mathrm{~B}$ \\
\hline $5 \%$ & 0.0624 & 0.0882 & 0.1399 & 0.1233 & 0.1743 & 0.2447 \\
\hline $1 \%$ & 0.0849 & 0.1201 & 0.1678 & 0.1678 & 0.2374 & 0.3316 \\
\hline
\end{tabular}

Average grain yield for all years and genotypes was the highest $\left(4.291 \mathrm{t} \mathrm{ha}^{-}\right.$ $\left.{ }^{1}\right)$ when nitrogen was applied at the level of $90 \mathrm{~kg} \mathrm{ha}^{-1}$. Application of $60 \mathrm{~kg} \mathrm{~N} \mathrm{ha}^{-1}$ $\left(4.093 \mathrm{t} \mathrm{ha}^{-1}\right)$ resulted in higher grain yield then application of $30 \mathrm{~kg} \mathrm{~N} \mathrm{ha}^{-1}(3.949 \mathrm{t}$ $\left.\mathrm{ha}^{-1}\right)$. Statistically minimal grain yield was recorded in the control $\left(3.749 \mathrm{t} \mathrm{ha}^{-1}\right)$. 
Increase in grain yield with an increase in nitrogen levels was also observed by Marinković et al. (2010); Duraisami and Mani (2001); Kumawat et al. (2000). Boroomanndan et al. (2009) obtained the highest grain yield of soybean at the level of $40 \mathrm{~kg} \mathrm{~N} \mathrm{ha}{ }^{-1}$ compared to control, but application of $80 \mathrm{~kg} \mathrm{~N} \mathrm{ha}{ }^{-1}$ decreased grain yield. Taylor et al. (2005) obtained the highest grain yield of soybean at the level from 60 to $70 \mathrm{~kg} \mathrm{~N}$ ha $^{-1}$.

Results showed that soybean variety Lana $\left(4.122 \mathrm{t} \mathrm{ha}^{-1}\right)$ produced higher yield than variety Laura $\left(3.937 \mathrm{t} \mathrm{ha}^{-1}\right)$. Soybean variety maturity group II had higher grain yield by $0.21 \mathrm{t} \mathrm{ha}^{-1}(4.35 \%)$ then variety of maturity group I $(4.832 \mathrm{t}$ $\left.\mathrm{ha}^{-1}\right)$ in 2008 , i.e. by $0.16 \mathrm{t} \mathrm{ha}^{-1}(5.26 \%)$ in 2009 . These differences were statistically significant.

In 2008, interaction between genotype and nitrogen level was significant, while this interaction was not significant in 2009.

Results suggested that the cultivars Lana and nitrogen level $90 \mathrm{~kg} \mathrm{ha}^{-1}$ could be used successfully for improving soybean yield in the region of Srem.

Protein content, in average for two years, two varieties and four nitrogen levels, was $32.73 \%$ (Table 2). In 2008, average protein content was higher by $0.98 \%(2.95 \%)$ then in 2009 (32.24\%).

All nitrogen fertilization levels increased the protein content, within interval from $1.65 \%\left(30 \mathrm{~kg} \mathrm{~N} \mathrm{ha}^{-1}\right)$ to $3.33 \%\left(90 \mathrm{~kg} \mathrm{~N} \mathrm{ha}^{-1}\right)$. In both research years, maximal protein content $(33.70 \%$ in 2008 and $32.68 \%$ in 2009) was recorded for level of $90 \mathrm{~kg} \mathrm{~N} \mathrm{ha}^{-1}$ in average for both genotypes. Minimal protein content was recorded in control (32.44\% in 2008 and $31.80 \%$ in 2009). These differences were statistically significant. Increase in protein content of soybean with increasing level of $\mathrm{N}$ was also reported by many researchers (Eman, 2002; Kumawat et al., 2000; Morshed et al., 2008; Đukić et al., 2010).

In average for both studied years, genotype Laura had higher protein content (33.16\%) then genotype Lana (32.30\%). Lana had lower protein content by $1.21 \%(3.58 \%)$ then Laura (33.83\%) in 2008. Laura had higher protein content by $0.5 \%(1.54 \%)$ then Lana $(31.99 \%)$ in 2009 . These differences were statistically significant.

In both research years interaction between genotype and nitrogen level was not significant.

Average oil content for years, hybrids and nitrogen levels, was $21.18 \%$. In 2009 , average oil content lower by $0.19 \%(0.89 \%)$ then in $2008(21.27 \%)$, Table 2. 
Average oil content for years, hybrids and nitrogen levels, was $21.18 \%$. In 2009, average oil content lower by $0.19 \%(0.89 \%)$ then in $2008(21.27 \%)$, Table 2.

Table 2. Effect of different nitrogen rates $\left(\mathrm{kg} \mathrm{ha}^{-1}\right)$ on protein content $(\%)$ and oil content $(\%)$ in soybean genotypes with reduced content of KTI

\begin{tabular}{|c|c|c|c|c|c|c|c|c|c|}
\hline \multirow[b]{2}{*}{ Year } & \multirow[b]{2}{*}{$\mathrm{N}$ levels (B) } & \multicolumn{4}{|c|}{ Protein content } & \multicolumn{4}{|c|}{ Oil content } \\
\hline & & Laura & Lana & $\mathrm{M}$ & Index, $\%$ & Laura & Lana & $\mathrm{M}$ & $\begin{array}{c}\text { Index, } \\
\%\end{array}$ \\
\hline \multirow{6}{*}{2008} & 0 & 33.01 & 31.88 & 32.44 & 100.00 & 21.32 & 21.66 & 21.49 & 100.00 \\
\hline & 30 & 33.84 & 32.59 & 33.22 & 102.40 & 21.26 & 21.37 & 21.32 & 99.21 \\
\hline & 60 & 34.06 & 32.96 & 33.51 & 103.30 & 21.20 & 21.18 & 21.19 & 98.60 \\
\hline & 90 & 34.38 & 33.02 & 33.70 & 103.88 & 21.15 & 21.00 & 21.08 & 98.09 \\
\hline & $\mathrm{M}$ & 33.83 & 32.62 & 33.22 & - & 21.23 & 21.30 & 21.27 & - \\
\hline & Index, $\%$ & 100.00 & 96.42 & 100.00 & - & 100.00 & 100.33 & 100.00 & - \\
\hline \multirow{6}{*}{2009} & 0 & 32.01 & 31.58 & 31.80 & 100.00 & 20.56 & 22.01 & 21.29 & 100.00 \\
\hline & 30 & 32.41 & 31.75 & 32.08 & 100.88 & 20.39 & 21.94 & 21.17 & 99.44 \\
\hline & 60 & 32.64 & 32.18 & 32.41 & 101.92 & 20.23 & 21.75 & 20.99 & 98.59 \\
\hline & 90 & 32.90 & 32.46 & 32.68 & 102.77 & 20.14 & 21.63 & 20.89 & 98.12 \\
\hline & $\mathrm{M}$ & 32.49 & 31.99 & 32.24 & - & 20.33 & 21.83 & 21.08 & - \\
\hline & Index, \% & 100.00 & 98.46 & 97.05 & - & 100.00 & 107.38 & 99.11 & - \\
\hline \multirow{6}{*}{ M } & 0 & 32.51 & 31.73 & 32.12 & 100.00 & 20.94 & 21.84 & 21.39 & 100.00 \\
\hline & 30 & 33.12 & 32.17 & 32.65 & 101.65 & 20.82 & 21.66 & 21.24 & 99.30 \\
\hline & 60 & 33.35 & 32.57 & 32.96 & 102.62 & 20.72 & 21.47 & 21.10 & 98.64 \\
\hline & 90 & 33.64 & 32.74 & 33.19 & 103.33 & 20.64 & 21.32 & 20.98 & 98.08 \\
\hline & $M$ & 33.16 & 32.30 & 32.73 & - & 20.78 & 21.57 & 21.18 & - \\
\hline & Index, $\%$ & 100.00 & 97.41 & - & - & 100.00 & 103.80 & - & - \\
\hline
\end{tabular}

\begin{tabular}{|c|c|c|c|c|c|c|}
\hline \multirow{2}{*}{$\mathrm{L}$} & \multicolumn{6}{|c|}{ Protein content } \\
\cline { 2 - 7 } $\mathrm{S}$ & \multicolumn{3}{|c|}{2008} & \multicolumn{2}{c|}{2009} \\
\cline { 2 - 7 } $\mathrm{D}$ & $\mathrm{A}$ & $\mathrm{B}$ & $\mathrm{A} * \mathrm{~B}$ & $\mathrm{~A}$ & $\mathrm{~B}$ & $\mathrm{~A} * \mathrm{~B}$ \\
\hline $5 \%$ & 0.5122 & 0.7243 & 1.1494 & 0.0740 & 0.1047 & 0.1658 \\
\hline $1 \%$ & 0.6973 & 0.9861 & 1.3781 & 0.1008 & 0.1426 & 0.1988 \\
\hline \multicolumn{7}{|c|}{ Oil content } \\
\hline $5 \%$ & 0.0671 & 0.0949 & 0.1506 & 0.1556 & 0.2201 & 0.3492 \\
\hline $1 \%$ & 0.0914 & 0.1292 & 0.1806 & 0.2119 & 0.2996 & 0.4187 \\
\hline
\end{tabular}

Seed oil content decreased while seed protein content increased with increased amounts of applied nitrogen. These results are in agreements with research Perić et al. (2009); Kolarić et al. (2009). Protein and oil content are negatively correlated and the protein content shows more variability than oil content.

All nitrogen fertilization levels decreased the oil content. In both research years, maximal oil content $(21.49 \%$ and $21.29 \%)$ was recorded in control in average for both genotypes. Minimal oil content $(21.08 \%$ and $20.89 \%)$ was recorded for level of $90 \mathrm{~kg} \mathrm{~N} \mathrm{ha}^{-1}$ in average for both genotypes. These differences were statistically significant. 
In average for both studied years, variety Lana produced higher oil content $(21.57 \%)$ then variety Laura $(20.78 \%)$. In 2008 , Lana had higher oil content for $0.33 \%$ then Laura $(21.23 \%$ ), while in 2009 it had $7.38 \%$ higher oil content then Laura (20.33). The difference recorded in 2009 was not statistically significant, while in 2008 it was statistically significant.

In 2008, interaction between genotype and nitrogen level was significant, while this interaction was not significant in 2009.

\title{
Conclusion
}

Variety Laura, with shorter vegetation period, produced lower grain yield and oil content then variety Lana. From this study it may be concluded that nitrogen had positive effect on grain yield and protein content of soybean genotypes with reduced content of KTI. The results of the study showed that application of $90 \mathrm{~kg} \mathrm{~N} \mathrm{ha}^{-1}$ increased the grain yield and protein content of soybean more than application of other treatments $\left(0,30\right.$ and $\left.60 \mathrm{~kg} \mathrm{~N} \mathrm{ha}^{-1}\right)$. All nitrogen fertilization levels decreased the oil content.

\section{Acknowledgment}

Research was financed by the project Education, Research and Training for Global Environmental Change and Sustainable Management of Natural Resources in West Balkan.

\section{Genotipski odgovor dve sorte soje sa smanjenim sadržajem KTI na primenu različitih količina azota}

\author{
V. Randjelović, S. Prodanović, Z. Tomić, Z. Bijelić
}

\section{Rezime}

Cilj istraživanja bio je da se odredi uticaj različite količine azota na prinos zrna i hranljivu vrednost zrna kod dva genotipa soje (Laura i Lana). Ispitivane sorte soje pripadaju različitim grupama zrenja (Laura - I i Lana - II) i imaju smanjeni sadržaj Kunitz tripsin inhibitora (KTI). Upoređivane su četiri varijante ishrane biljaka azotom: $0 \mathrm{~kg} \mathrm{~N} \mathrm{ha}^{-1}, 30 \mathrm{~kg} \mathrm{~N}$ ha $^{-1}, 60 \mathrm{~kg} \mathrm{~N} \mathrm{ha}^{-1}$ i $90 \mathrm{~kg} \mathrm{~N} \mathrm{ha}^{-1}$. Ogledi su izvedeni u suvom ratarenju, na lokaciji Putinci, tokom 2008. i 2009. godine. U obe godine istraživanja, sorta Lana imala je veći prinos zrna i sadržaj ulja nego sorta Laura. Ishrana azotom pokazala se kao uspešna metoda za poboljšanje prinosa zrna 
i sadržaja proteina kod obe sorte. Rezultati istraživanja pokazali su da je primena $90 \mathrm{~kg} \mathrm{~N} \mathrm{ha}^{-1}$ povećala prinos zrna soje i sadržaj proteina u zrnu više nego primena drugih tretmana $\left(0,30\right.$ i $\left.60 \mathrm{~kg} \mathrm{~N} \mathrm{ha}^{-1}\right)$. Svi nivoi ishrane azotom smanjili su sadržaj ulja.

\section{References}

BOROOMANDAN P., KHORAMIVAFA M., HAGHI Y., EBRAHIMI A. (2009): The effects of nitrogen starter fertilizer and plant density on yield, yield components and oil and protein content of soybean (Glycine max, Merr.). Pakistan Journal of Biological Sciences, 12, 4, 378-382.

GLAMOČLIJA Đ. (2004) Posebno ratarstvo. Žita i zrnene mahunarke. Beograd: Draganić.

DURAISAMI V.P., MANI A.K. (2001): Residual effect of inorganic nitrogen, composted coirpith and biofertilizer on yield and uptake of soybean in an Inceptisol. Madras Agricultural Journal, 88, 4-6, 277-280.

ĐUKIĆ V., ĐORĐEVIĆ V., POPOVIĆ V., KOSTIĆ M., ILIĆ A., DOZET G. (2009): Uticaj đubrenja na prinos soje. Ratarstvo i povrtarstvo / Field and Vegetable Crops Research, 46, 17-22.

EMAN S.S. (2002): Response of growth, yield and attributes of soybean plants (Glycin max (L.) Merr.) to late soil nitrogen fertilization. Arab Universities Journal of Agricultural Sciences, 10, 1, 165-172.

KUMAWAT S.M., DHAKAR L.L., MALIWAL P.L. (2000): Effect of irrigation regimes and nitrogen on yield, oil content and nutrient uptake of soybean (Glycine max). Indian Journal of Agronomy, 45, 2, 361-366.

MARINKOVIĆ J., MRKOVAČKI N., AĆIMOVIĆ, R., ĐORĐEVIĆ V. (2010): Uticaj primene NS-Nitragina na prinos i komponente prinosa kod soje. Ratarstvo i povrtarstvo / Field and Vegetable Crops Research, 47, 545-548.

MIKIĆ A., PERIĆ V., ĐORĐEVIĆ V., SREBRIĆ M., MIHAILOVIĆ M. (2009): Anti-nutritional factors in some grain legumes. Biotechnology in Animal Husbandry 25, 5-6, 1181-1188.

MORSHED R.M., RAHMAN M.M., RAHMAN M.A. (2008): Effect of Nitrogen on Seed Yield, Protein Content and Nutrient Uptake of Soybean (Glycine max L.). Agriculture and Rural Development, 6, 1-2, 13-17.

PERIĆ V., SREBRIĆ M., JANKULOSKI LJ., ŽILIĆ S., JANKULOSKA M., KANDIĆ V., MLADENOVIĆ-DRINIĆ S. (2009): The effects of nitrogen on protein, oil and trypsin inhibitor content of soybean. Genetika, 41, 2, 137-144.

KOLARIĆ LJ., GLAMOČLIJA Đ., ŽIVANOVIĆ LJ., SREBRIĆ M., PERIĆ V. (2009): Uticaj količine azota na prinos i kvalitet odabranih genotipova soje. Zbornik naučnih radova Instituta PKB Agroekonomik, 15, 1-2, 73-80. 
RANĐELOVIĆ V., PRODANOVIĆ S., PRIJIĆ LJ., GLAMOČLIJA Đ., ŽIVANOVIĆ LJ., KOLARIĆ LJ. (2009): Uticaj folijarnog prihranjivanja u stresnim uslovima na dve sorte soje različitih grupa zrenja. Zbornik naučnih radova Instituta PKB Agroekonomik, 15, 1-2, 67-72.

SCHMITT A.M., LAMB A.J., RANDALL W.G., ORF H.J., REHM W.G. (2001): In-sea son Fertilizer Nitrogen Applications for Soybean in Minnesota. Agronomy Journal, 93, 983-988.

SREBRIĆ M., PERIĆ V. (2008): Breeding of Kunitz-free soybean genotypes. Proceedings of 18th EUCARPIA General Congress Modern Variety Breeding for Present and Future Needs, Valencia, Spain, 9-12 September 2008, 640.

STARLING M.E., WOOD C.W., WEAVER D.B. (2000): Late-planted soybeans respond to nitrogen starter. Fluid J., 28, 26-30.

TAYLOR S.R., WEAVER B.D., WOOD C.W., SANTEN VAN E. (2005): Nitrogen application in creases yield and early dry matter accumulation in lateplanted soybean. Crop Science 45, 854-858.

WESLEY T.L., LAMOND R.M., MARTIN V.L., DUNCAN R.S. (1998): Effects of late-season nitrogen fertilizer on irrigated soybean yield and composition. Journal of Production Agriculture 11, 331-336.

ŽIVANOVIĆ LJ., NENADIĆ N., TOMIĆ B. (2000): Uticaj načina ishrane azotom i vremena setve na prinos soje. Zbornik naučnih radova Instituta PKB

Agroekonomik, 8, 1, 128-130.

Received 28 July 2010; accepted for publication 15 September 2010 